\title{
GAYA KEPEMIMPINAN PEREMPUAN DALAM INSTANSI PUBLIK: STUDI PADA KEPEMIMPINAN SUSI PUDJIASTUTI
}

\author{
Aulia Hanadita Balkis \\ Departemen Ilmu Administasi Negara, Fakultas Ilmu Administrasi, Universitas \\ Indonesia \\ Aulia.hanadita@ui.ac.id
}

\begin{abstract}
ABSTRAK
Pro dan Kontra mengenai kepemimpinan perempuan di Indonesia merupakan masalah krusial yang selalu diperbincangkan setiap tahunnya. Kuatnya stereotype terhadap pemimpin yang harus berasal dari gender laki-laki yang bersifat tegas dan kuat membuat pemimpin perempuan dianggap sebelah mata di masyarakat. Penelitian ini menggunakan metode pendekatan data kualitatif dan analisis deskriptif terhadap sumber data sekunder yang diperoleh dari berbagai dokumen serta sumber berita dari laman web. Hasil dari penelitian ini adalah gender tidak berpengaruh dalam kepemimpinan seseorang. Susi Pudjiastuti sebagai Menteri Kelautan dan Perikanan cenderung menggunakan kepemimpinan transformasional, karena memiliki sifat maskulinitas namun mampu menghasilkan beberapa program yang menguntungkan bagi seluruh bidang. Dalam masa kepemimpinannya, beliau berhasil mendapatkan prestasi kerja yang belum pernah didapatkan oleh menteri yang terdahulu.
\end{abstract}

Kata Kunci: Kepemimpimam Perempuan; Instansi Publik; Susi Pudjiastuti.

\begin{abstract}
Pros and cons of women's leadership in Indonesia is a crucial issue that is always discussed every year. The strong stereotype of leaders that must come from male gender that is firm and strong makes women leaders considered one eye in society. This study uses a qualitative data approach and descriptive analysis of secondary data sources obtained from various documents and news sources from web pages. The results of this study are that gender has no effect on one's leadership. Susi Pudjiastuti as Minister of Maritime Affairs and Fisheries tends to use transformational leadership, because she has the character of masculinity but able to produce several programs that benefit all sectors. During her leadership, she managed to get work achievements that had never been obtained by the previous minister.
\end{abstract}

Keywords: women's leadership; public agency; Susi Pudjiastuti. 


\section{PENDAHULUAN}

Kesetaraan gender merupakan sebuah tantangan yang selalu diperjuangkan dari tahun ke tahun, karena posisi perempuan dianggap belum setara dengan laki-laki. World Economic Forum (WEF) mengkaji isu gender gap yang terjadi di empat sektor yang memiliki kontribusi besar dalam negara, yaitu kesehatan, pendidikan, ekonomi, dan pemberdayaan politik, hingga pada akhir tahun 2016 perkembangan isu gender gap masih dikategorikan lambat (Sitorus, 2016). Jumlah perempuan yang terlibat dalam peran kepemimpinan hanya $34 \%$ secara global, dimana perempuan secara proporsional lebih sedikit dibandingkan pria dalam angkatan kerja (DW.com, 2018).

Kepemimpinan perempuan dalam suatu negara dimulai pada abad ke19 oleh para pejuang feminism liberal. Hal ini dikarenakan timbulnya kesadaran bahwa dalam suatu negara dibutuhkan kesetaraan antara laki-laki dan perempuan. Namun perjuangan tersebut dianggap lemah karena pengaruh dari budaya maskulinitas (Astuti, 2019). Nilainilai maskulinitas yang dominan dianggap menjadi kriteria utama dalam dunia politik sehinga politik sering kali dianggap dunia maskulinitas (Rifka, 2009). Hal tersebut mendorong hadirnya perempuan yang maskulin, hasil dari pengaruh peraturan dalam lapangan kerja yang cenderung bersifat maskulin.

Perjuangan perempuan di Indonesia mulai timbul ketika terdapatnya organisasi perempuan hingga adanya keterlibatan perempuan Indonesia dalam tatanan negara (Irenewaty \& Trimurtini, 2015). Pada saat ini, perempuan diperbolehkan untuk menjadi seorang pemimpin dalam tatanan struktur kabinet maupun legistlatif. Hal ini dibuktikan dalam "Kabinet Kerja" Presiden Joko Widodo pada tahun 2014 yang memuat delapan menteri perempuan (Kompas.com, 2014). Salah satu menteri yang memiliki gaya kepemimpinan maskulin adalah Menteri Kelautan dan Perikanan Susi Pudjiastuti.

Menteri Susi Pudjiastuti merupakan menteri kelautan dan perikanan ke-6 di Indonesia. Pada saat masa kepemimpinannya, beliau dikenal dengan sosok yang tegas dan berani. Hal ini ditunjukan dengan tindakannya yang berani untuk menenggelamkan kapal asing yang masuk secara illegal di Indonesia (Hananya \& Azzahra, 2017). Meskipun kepemimpin perempuan di Indonesia masih dianggap rendah, namun menteri Susi mampu membuktikan dengan kinerja yang baik.

Oleh karena itu, artikel ini akan membahas mengenai bagaimana gaya kepemimpinan Susi Pudjiastuti dalam instansi publik? Tujuan penulisan artikel ini bertujuan untuk mengetahui gaya kepemimpinan Susi Pudjiastuti dalam instansi publik. Kepemimpinan adalah kemampuan seseorang untuk mengerrakan dan mempengaruhi seseorang untuk mencapai suatu tujuan (Sutikno, 2014). Selain itu kepemimpinan adalah kemampuan seseorang untuk mempengaruhi orang lain, dan orang yang diperintahkannya mengikutinya tanpa adanya kekerasan terlebih dahulu (Moorhead \& Griffin, 2013). Pendapat lain mengatakan bahwa kepemimpinan adalah bagaimana mempengaruhi orang lain untuk setuju mengenai apa yang dibutuhkan untuk dilakukan dan bagaimana mengerjakan tugas secara efektif untuk mencapai tujuan organisasi (Yukl, 2010).

Dalam memimpin, seorang pemimpin memiliki tipe tersendiri yang membedakan antara pemimpin yang satu dengan yang lainnya. Berikut adalah tipe kepemimpinan: 
a. Kepemimpinan Otoriter: Tipe kepemimpinan ini berifat sentralistik pada pemimpin sebagi penentu dan pengendali anggota dan kegiatan organisasi untuk mencapai tujuan organisasi. Dalam hal ini, anggota organisasi tidak memiliki hak apapun, melainkan hanya memiliki kewajiban dan tanggung jawab untuk melaksanakan perintah pemimpin.

b. Kepemimpinan Demokratis: Tipe kepemimpinan ini lebih menekankan pada manusia memiliki hak asasi yang sama.

c. Kepempinan Bebas (Laissez Faire): Tipe kepemimpinan ini menganggap bahwa setiap anggota organisasi memiliki kecakapan untuk membuat keputusan dan mampu mengurus dirinya masing-masing dengan sedikit arahan dalam mengerjakan tugasnya.

Gaya kepemimpinan merupakan cara seseorang memimpin perilaku bawahan untuk mendorong etos kerja, produktivitas kerja dalam rangka mencapai tujuan organisasi (Hasibuan, 2016). Terdapat beberapa jenis gaya kepemimpinan, diantaranya (Robbins \& Judge, 2008):

a. Gaya Kepemipinan Kharismatik, dimana para bawahan memiliki suatu kesan tersendiri kepada pemimpin mereka. Ciri dari pemimpin yang memiliki gaya kharismatik adalah visi dan artikulasi, resiko personal, peka terhadap lingkungan, kepekaan terhadap kebutuhan pengikut, perilaku tidak konvensional.

b. Gaya Kepemimpinan Transaksional, yaitu pemimpin memberikan motivasi kepada bawahannya dengan cara membuat tujuan yang jelas dengan peran dan tugas. Terdiri atas: a) imbalan kontingen, b) manajemen berdasarkan pengecualian (aktif), c) manajemen berdasarkan pengecualian (pasif), d) Laissez Faire dengan melepas tanggung jawab dan menghindari pembuatan keputusan.

c. Gaya Kepemimpinan Transformasional, yaitu pemimpin lebih memfokuskan pada pengembangan para bawahannya dengan cara mengubah kesadaran bawahan untuk menyelesaikan masalah dengan cara-cara baru, membangkitkan dan mengeluarkan tindakan lebih untuk mencapai tujuan organisasi.

d. Gaya Kepemimpinan Visioner, yaitu pemimpin membuat visi yang realistis, kredibel, dan menarik untuk masa depan organisasinya.

Di dunia, jumlah perempuan lebih mayoritas dibandingkan dengan jumlah pria. Apabila kapasitas perempuan yang banyak tersebut lebih dilibatkan dalam pengambilan keputusan, maka arahpolitik juga akan berubah(Pudji, 2011). Politik akan lebih peka terhadap masalah-masalah yang awalnya dianggap bukan informasi politik seperti kesejahteraan anak, perlindungan terhadap reproduksi perempuan, dan lain-lain. Kehidupan politik akan lebih bernilai karena perempuan cenderung mementingkan isu politik konvensional seperti ekonomi, pendidikan, perumahan, lingkungan, kesejahteraan sosial daripada politik keras seperti peningkatan tentara, perang, pembelian senjata, dan membuat senjata nuklir (Pudji, 2011). 


\section{METODE PENELITIAN}

Pendekatan penulisan dilakukan dengan metode pendekatan data kualitatif dan analisis deskriptif terhadap sumber data sekunder yang diperoleh dari berbagai dokumen serta sumber berita dari laman web. Penelitian deskriptif kualitatif merupakan metode penulisan yang memiliki tujuan mendeskripsikan peristiwa atau fenomena yang terjadi di lapangan serta menyajikan data secara faktual, sistematis, dan akurat(Bagong \& Sutinah, 2005). Penulisan karya tulis ini merujuk pada pengumpulan data dilakukan dengan cara studi kepustakaan (literature review) baik sumber primer, yaitu dokumen yang ditulis langsung oleh pengarang serta sumber sekunder, yaitu dokumen berupa laporan oleh pengarang (Hadi, 2005).

\section{HASIL DAN PEMBAHASAN}

Susi Pudjiastuti Sebagai Pemimpin dalam Kementrian Kelautan dan Perikanan

Pro dan kontra mengenai kepemimpinan merupakan permasalahan yang terus terjadi di Indonesia. Masyarakat Indonesia cenderung belum bisa menerima jika seorang perempuan menempati jabatan tinggi di instansi publik (Mewengkang, Mandey, \& Ruru, 2016). Namun dalam implementasinya kepemimpinan perempuan pun dapat menjadi aset sosial bagi pembangunan bangsa. Selama masa kepemimpinannya, Susi Pudjiastutidikenal memiliki sifat yang tegas, berani dan cenderung menghasilkan kebijakan yang out of the box. Salah satu kebijakan tersebut adalah penenggelaman kapal nelayan illegal yang mencuri ikan di perairan Indonesia.

Dampak kebijakan Susi Pudjiastuti untuk menenggelamkan kapal nelayan asing tersebut menimbulkan ketegangan hubungan diplomasi antara Indonesia dengan Vietnam. Hal ini dikarenakan selama tahun 2018 ditemukan 83 kapal milik Vietnam yang ditenggelamkan oleh Susi Pudjiastuti. Bahkan menurut data yang diperoleh dari Food and Agriculture Organization ( $F A O$ ), terdapat 5400 kapal yang masuk ke Indonesia untuk melakukan illegal fishing (wwf.or.id, 2015). Namun, kebijakan tersebut membawa dampak positif terhadap peningkatan pendapatan rata-rata nelayan Indonesia, dimana dengan adanya kebijakan tersebut pendapatan para nelayan meningkat cukup pesat dari tahun 2015 hingga 2018. Berdasarkan data laporan KKP 2018, pada tahun 2015, rata-rata pendapatan nelayan sebesar Rp 1,9 juta setiap bulan. Pada 2016 pendapatan tersebut meningkat menjadi Rpp 2,1 juta per bulan, kemudian pada tahun 2017 naik menjadi Rp 2,2 juta per bulan. Pada 2018, pendapatan rata-rata nelayan sebesar Rp 2,4 juta per bulan (Said, 2019).

Dalam masa kepemimpinannya Susi Pudjiastuti mendapatkan penghargaan atas kinerjanya. Beberapa penghargaan tersebut diantaranya adalah menjadi Leaders for a Living Planet Awards yang diberikan dari World Wide Fund for Nature (WWF) Internasional pada tahun 2016 atas dasar individy yang memberikan kontribusi yang besar terhadap konservasi alam dan pembangunan berkelanjutan (wwf.or.id, Susi Pudjiastuti Terima Penghargaan WWF Leaders for a Living Planet, 2016), kemudian menjadi bagian dari 100 Pemikir Terbaik Dunia versi majalah Foreign Policy. Hal 
tersebut dikarenakan keberanian Susi Pudjiastuti dalam memerangi pencurian ikan. Selain itu, Susi Pudjiastuti juga menerima penghargaan Peter Benchley Ocean Awardsatas dasar visi dan kebijakan pembangunan ekonomi dan konservasi laut di Indonesia (Said, 2019).

Gaya Kepemimpinan Menteri Susi Pudjiastuti

Dalam masa kepemimpinannya, Susi Pudjiastuti cenderung menggunakan gaya kepemimpinan transformasional. Hal ini dapat dilihat dalam masa kepemimpinannya, Susi Pudjiastuti cenderung bersifat sebagai penggerak, dan memiliki jiwa yang maskulinitas (Nurchayati \& Hariyanti, 2017). Susi Pudjiastuti cenderung menggunakan cara baru dalam menyelesaikan masalah-masalah yang ada sepertipenanggulangan illegal fishing yaitu dengan cara penenggelaman kapal serta larangan transshipment di tengah laut seperti yang termuat dalam Peraturan Presiden Nomor 115 tahun 2015 tentang Satuan Tugas Pemberantasan Illegal Fishing (Isnurhadi, 2017). Hal ini dilakukan untuk memberikan efek jera kepada kapal asing yang masuk ke Indonesia tanpa izin. Namun, sebelum kapal tersebut ditenggelamkan kapal tersebut sudah dibersihkan, mesin dan bahan bakar sudah dipisahkan, sehingga penenggelaman kapal tidak mencemari laut karena kapal-kapal yang ditenggelamkan nantinya akan menjadi tempat bagi ikan dan diving site baru (Wijaya \& Marta, 2019).

Dimana dampak dari program tersebut justru menguntungkan para nelayan, karena pertumbuhan perikanan meningkat hingga mencapai 8,96\%. Pada tahun 2014 pertumbuhannya $8,3 \%$, kemudian meningkat menjadi 8,7\%, lalu di tahun 2015 menjadi 8,96\%. Berdasarkan perhitungan Badan Pusat Statistik (BPS), dibandingkan dengan November 2014, nilai tukar nelayan pada 2015 mampu mencapai 106,12\% sedangkan sebelumnya hanya 104,2\% (BBCnews, 2016). Akibat dari kenaikan jumlah ikan di Indonesia membuat konsumsi di Indonesia pun meningkat sebanyak 37,89 kg/kapita (Hafni \& Sutjipto, 2019). Hal ini merupakan perubahan yang sangat drastis dilakukan oleh seorang Menteri Kelautan dan Perikanan, karena meskipun kondisi ekonomi baik, sektor perikanan sebelumnya tidak pernah melebih 6\%. Namun, ketika Susi Pudjiastuti menjadi menteri dengan keadaan ekonomi yang buruk justru dapat meningkatkan pertumbuhan perikanan (BBCnews, 2016). Selain itu, program tersebut juga membuat terjadinya penurunan ekspor ikan di Thailand maupun Filipina, tetapi ekspor ikan Indonesia jusru meningkat. Ekspor ikan tuna Indonesia kepada Amerika Serikat (AS) selama Januari-September 2015 mengalami kenaikan sebesar 7,73\%. Pada waktu yang sama ekspor Tuna Thailand dan Filipina ke Amerika Serikat justru mengalami penurunan sebesar 32,59\%, sehingga menyebabkan Pertumbuhan Produk Domestik Bruto (PDB) di sektor perikanan meningkat. PDB perikanan Januari-September 2015 meningkat menjadi $8,37 \%$, jauh diatas rata-rata kenaikan PDB nasional yang hanya sebesar 4,73\% (Agustinus \& Idris, 2015).

Pemberantasan illegal fishing yang dilakukan melalui program penenggelaman kapal memberikan dampak positif dalam penegakan hukum (Efrtitadewi \& Jefrizal, 2017). Salah satu dampak yang sangat siginifikan adalah berkurangnya sampah di laut Indonesia. Hal ini dikarenakan mayoritas sampah berasal dari kapal illegal besar yang 
datang ke Indonesia dan membawa sampah yang cukup banyak. Selain itu, Susi Pudjiastuti juga melakukan kerja sama dengan departemen perhubungan, lingkungan hidup, dan KPP untuk melakukan sosialisasi untuk mengubah budaya agar tidak membuangnya ke laut(Romadoni, 2015). Sehingga, Indonesia berhasil dinobatkan menjadi negara yang berhasil dalam pemberantasan illegal fishingoleh Perdana Menteri Norwegia (Republika.co.id, 2019).

Pada saat masih menjabat sebagai menteri, Susi Pudjiastuti cenderung menggunakan kepemimpinan transformasional. Hal ini dibuktikan dengan pada saat masa kepemimpinannya, Susi Pudjiastuti berhasil memperoleh penghargaan dari Foundation for International Human Rights Reporting Standards (FIHRRST). Penghargaan tersebut diberikan karena Kementrian Kelautan dan Perikanan merupakan kementrian pertama yang mengimplementasikan terobosan norma hak asasi manusia (HAM) dalam kebijakan pemerintah. Pedoman pelaksanaan HAM yang dikeluarkan oleh Kementrian Kelautan dan Perikanan juga sesuai dengan petunjuk yang dikeluarkan oleh PBB.

Menurut Susi, dunia bisnis dibidang perikanan erat kaitannya dengan perlindungan HAM. Oleh karena itu, Kementrian Kelautan dan Perikanan sebagai pembuat kebijakan ingin memastikan bahwa hak-hak para nelayan lebih dihargai dengan cara seluruh Anak Buah Kapal (ABK) wajib memiliki BPJS (Suryowati, Susi Dipuji, KKP Kementerian Pertama yang Peduli Soal HAM, 2015).

Dalam kepemimpinannya, Susi Pudjiastuti mengalokasikan anggaran sebesar Rp 100 miliar per pulau untuk mengangkat perekonomian masyarakat di pulau kecil dan terluar (Talumantak, 2018). Daerah yang sudah mengikuti program pengembangan ini diantaranya adalah Simeulue, Natuna, Sangihe, Merauke, dan Saumlaki. Program pengembangan pulau kecil dan terluar ini merupakan prioritas dari Kementrian Kelautan dan Perikanan karena pulau tersebut sangat penting untuk kesatuan NKRI. Sebab jika pulau tersebut dijual kepada negara lain maka Indonesia akan kehilangan batas wilayah (Suryowati, 2015).

Dalam masa kepemimpinannya, Susi Pudjiatuti cenderung mengeluarkan tindakan yang lebih seperti yang temuat dalam misinya. Salah satu misi Susi Pudjiastuti sebagi menteri adalah mensejahterakan para nelayan dan memajukan kesejahteraan rakyat Indonesia (Hadi, Syarifudin, \& Alfath, 2018). Salah satu cara yang ditempuh untuk mewujudkan visi tersebut adalah dengan cara memberikan gajinya selama menjabat menjadi meteri kepada nelayan tua, panti jompo, dan pembuatan asuransi bagi para nelayan (Kristiadi, 2014). Hal tersebut dilakukan karena menurut Susi Pudjiastuti masih banyak nelayan yang memiliki kehidupan yang kurang layak dan berada dibawah garis kemiskinan (Widodo, 2009). Sehingga beliau spontan melakukan tindakan tersebut setelah menerima keluhan dari para nelayan.

Program lain yang dibuat oleh Susi Pudjiastuti dalam masa kepemimpinannya adalah membuat perahu bermuatan 5 hingga 30 gross ton untuk para nelayan, dan membantu membudidayakan perikanan. Selain itu juga, Susi Pudjiastuti membuat lemari es pendingin di beberapa daerah, kemudian membuat mesin es untuk kampung nelayan (BBC.com, 2016). Salah satu daerah yang telah dibuatkan mesin es adalah di kawasan 
Muara Baru, Jakarta Utara. Dimana lemari es tersebut memiliki kapasitas 1.000 ton yang dibuat di atas lahan seluas 8.885 meter persegi dengan luas bangunan 5619 meter persegi yang terdiri dari 2 lantai dan 1 mezanin. Hal ini berfungsi untuk menampung ikan yang berasal dari sentra produksi, sehingga tidak menyebabkan ikan terbuang dan harga tetap stabil (Kumparan.com, 2019).

\section{PENUTUP}

Pro dan kontra akan kepemimpinan yang dipimpin oleh perempuan merupakan isu yang selalu menjadi bahasan setiap tahunnya. Namun, melihat dari kinerja Susi Pudjiastuti maka dapat dilihat bahwa perempuan pun mampu melakukan pekerjaan yang sama dengan seorang pria. Dalam masa kepemimpinannya, Susi Pudjiastusi cenderung menggunakan gaya kepemimpinan transformasional. Dimana beliau memiliki sifat yang tegas dan bersifat sebagi penggerak sehingga berhasil menciptakan beberapa program yang manfaatnya dapat dirasakan. Hal tersebut menampik bahwa pemimpin bahwa kepemimpinan yang tegas dan kuat dalam memegang kuat prinsip kedaulatan khususnya di instansi publik tidak hanya dimiliki oleh pemimpin laki-laki. Sehingga kedepan dalam pemilihan atau penunjukan pemimpin perempuan di instansi publikselayaknya sudah tidak lagi mempertentangkan antara laki-laki dan perempuan karena tidak releven terkait dengan kemampuan dan kinerja yang berdampak pada pencapaian organisasi.

\section{DAFTAR PUSTAKA}

Agustinus, M., \& Idris, M. (2015, Desember 29). Ini Dampak Kebijakan Menteri Susi Perangi Illegal Fishing. Retrieved Mei 16, 2020, from DetikFinance: https://finance.detik.com/berita-ekonomi-bisnis/d-3106647/ini-dampak-kebijakanmenteri-susi-perangi-illegal-fishing

Astuti, R. P. (2019). Optimalisasi Pemberdayaan Perempuan dalam Kepemimpinan Efektif. Jurnal An-Nisa Vol.12, 12.

Bagong, S., \& Sutinah. (2005). Metode Penelitian Sosial Berbagai AlternatifPendekatan. Yogyakarta: Pustaka.

BBC.com. (2016, Maret 5). Susi Pudjiastuti: pemerintah harus berani buat moratorium reklamasi . Retrieved Juni 13, 2020, from BBC: https://www.bbc.com/indonesia/berita_indonesia/2016/03/160305_indonesia_wwc_ menteri_susi

BBCnews. (2016, Maret 5). Susi Pudjiastuti: pemerintah harus berani buat moratorium reklamasi . Retrieved Mei 16, 2020, from BBC NEWS: https://www.bbc.com/indonesia/berita_indonesia/2016/03/160305_indonesia_wwc_ menteri_susi

DW.com. (2018, Desemberr 18). WEF: Kesetaraan Gender di Dunia Kerja Masih Perlu 'Lebih 200 Tahun'. Retrieved Mei 14, 2020, from DW.COM: https://www.dw.com/id/wef-kesetaraan-gender-di-dunia-kerja-masih-perlu-lebih200-tahun/a-46784378 
Efrtitadewi, A., \& Jefrizal, W. (2017). Penenggelaman Kapal Illegal Fishing di Wilayah Indonesia dalam Perspektif Hukum Internasional. Jurnal Selat Vol. 4 No.2 , 144272.

Hadi, S. (2005). Statistik II. Jakarta: PT. Rineka Cipta.

Hasibuan, M. S. (2016). Manajemen Sumber Daya Manusia. . Jakarta: PT Bumi Aksara. Hadi, S., Syarifudin, T. Y., \& Alfath, T. P. (2018). Perlindugan Hak Asasi Manusia dalam Reklamasi di Wilayah Pesisir dan Pulau-Pulau Kecil. Jurnal Unnes Vol.2 No.2 , 219.

Hafni, R. D., \& Sutjipto, V. W. (2019). Faktor-Faktor Komunikasi Persuasif Susi Pudjiastuti dalam Membangun Kepercayaan Masyarakat Untuk Mengkonsumsi Ikan. Jurnal Perspektif Komunikasi Vol. 3 No.2 , 119-124.

Hananya, K. A., \& Azzahra, F. S. (2017). Indonesia sebagai Kekuatan Menengah: Komparasi Respon Indonesia terhadap Illegal Fishing dan Laut Tiongkok Selatan. Jurnal Hubungan Internasional Vol. 10, No.2 , 58.

Isnurhadi, M. R. (2017). Sekuritisasi Illegal, Unreported, Unregulated Fishing (IUUF) di Perairan Indonesia di Era Pemerintahan Joko Widodo. Jurnal Hubungan Internasional Unair Vol.10, No.2, 13-15.

Irenewaty, T., \& Trimurtini, W. (2015). Perkembangan Kongres Perempuan Indonesia pertama th 1928 di Yogyakarta . Perpustakaan FIS .

Kompas.com. (2014, Oktober 27). 8 Kursi Menteri Perempuan di Kabinet Kerja, Terbanyak dalam Sejarah. Retrieved Mei 14, 2020, from Kompas.com: https://nasional.kompas.com/read/2014/10/27/01430051/8.Kursi.Menteri.Perempu an.di.Kabinet.Kerja.Terbanyak.dalam.Sejarah

Kristiadi. (2014, November 1). Susi Hibahkan Gaji, Nelayan Renta Sambut Gembira. Retrieved Mei 16, 2020, from medcom.id: https://www.medcom.id/nasional/daerah/nbwYBZEK-susi-hibahkan-gaji-nelayanrenta-sambut-gembira

Kumparan.com. (2019, Oktober 10). Susi Pudjiastuti Resmikan Cold Storage Raksasa: Ini Bisa Disewa. Retrieved Juni 13, 2020, from Kumparan.com: https://kumparan.com/kumparanbisnis/susi-pudjiastuti-resmikan-cold-storageraksasa-ini-bisa-disewa-1s1jXtdi7k6/full

Mewengkang, L., Mandey, J., \& Ruru, J. M. (2016). Peranan Kepemimpinan Perempuan dalam Jabatan Publik (Studi Pada Kantor Sekretariat Daerah Kabupaten Minahasan Selatan). Jurnal Administrasi Publik Vol. 2, No. 044 , 3.

Nurchayati, Z., \& Hariyanti, N. (2017). Analisis Resepsi dan Identitas Kepemimpinan Perempuan. Jurnal Sosial Vol.18, No. 1, 115-116. 
Moorhead, \& Griffin. (2013). Perilaku Organisasi. Jakarta: Salemba Empat.

Pudji, A. T. (2011). Konstruksi Gender Dalam Realitas Sosial. Semarang: Unnes Press.

Republika.co.id. (2019, September 29). Pemberantasan Ilegal Fishing, Norwegia Apresiasi Indonesia. Retrieved Juni 13, 2020, from Republika.co.id: https://republika.co.id/berita/pyl65u423/pemberantasan-ilegal-fishing-norwegiaapresiasi-indonesia

Romadoni, A. (2015, Oktober 20). Menteri Susi: Indonesia Juara 1 Pemberantasan Illegal Fishing. Retrieved Mei 16, 2020, from Liputan6.com: https://www.liputan6.com/news/read/2344777/menteri-susi-indonesia-juara-1pemberantasan-illegal-fishing\#

Rifka. (2009). Spirit Feminis dalam Berpolitik. Yogyakarta.

Robbins, S. P., \& Judge, T. A. (2008). Perilaku Organisasi Edisi ke-12. Jakarta: Salemba Empat.

Sutikno, S. M. (2014). Pemimpin dan Gaya Kepemimpinan. Lombok: Holistica.

Said, A. A. (2019, Agustus 19). Susi Pudjiastuti, Menteri Nyentrik yang Paling Berpengaruh di Twitter. Retrieved Mei 15, 2020, from katadata.co.id: https://katadata.co.id/berita/2019/08/19/susi-pudjiastuti-menteri-nyentrik-yangpaling-berpengaruh-di-twitter

Suryowati, E. (2015, Agustus 20). Menteri Susi Gelontorkan Rp 100 Miliar untuk Pulaupulau Terluar. Retrieved Mei 16, 2020, from Kompas.com: https://money.kompas.com/read/2015/08/20/113500826/Menteri.Susi.Gelontorka n.Rp.100.Miliar.untuk.Pulau-pulau.Terluar

Suryowati, E. (2015, November 30). Susi Dipuji, KKP Kementerian Pertama yang Peduli Soal HAM. Retrieved Mei 16, 2020, from Kompas.com: https://money.kompas.com/read/2015/11/30/134234926/Susi.Dipuji.KKP.Kement erian.Pertama.yang.Peduli.Soal.HAM

Sitorus, A. V. (2016). Dampak Ketimpangan Gender Terhadap Pertumbuhan Ekonomi di Indonesia. Jurnal Kemsos Vol.2, No.1 , 94.

Talumantak, P. (2018). Penegakan Hukum terhadap Pulau-Pulau Terluar Indonesia untuk Keutuhan Wilayah Negara Kesatuan Republik Indonesia. Lex Et Societatis Vol.6, No. $10,138-139$.

Widodo, S. (2009). Stratego Nafkah Rumah Tangga Nelayan dalam Menghadapi Kemiskinan. Jurnal Kelautan Vol.2, No.2 , 150-153.

Wijaya, C., \& Marta, D. (2019, Mei 4). Menteri Susi kembali tenggelamkan kapal: 'Ini way out yang sangat cantik untuk bangsa kita, menakutkan untuk bangsa lainnya'. Retrieved Mei 16, 2020, from BBC News: https://www.bbc.com/indonesia/indonesia-48131222 
wwf.or.id. (2015, Maret 23). Memberantas Pelaku Kejahatan Perikanan. Retrieved Juni 12, 2020, from WWF: https://www.wwf.or.id/?38242/Memberantas-PelakuKejahatan-Perikanan

wwf.or.id. (2016, September 18). Susi Pudjiastuti Terima Penghargaan WWF Leaders for a Living Planet. Retrieved Juni 12, 2020, from WWF: https://www.wwf.or.id/?50982/Susi-Pudjiastuti-Terima-Penghargaan-WWFLeaders-for-a-Living-Planet 